\section{Sollected Gatars:}

\section{ANTPOTAC GFFEOT OF CHLOROFORM ON SIRYCHNINE.}

By W. H. Gonrmcar, Profóssior of Anatomy in tho Medical College of Ohio.

EarLY in the morning of Thursday, December 5th, 1867, I was called to the Gibson House, Cincinnati, Ohio, to visit a young man, aged about 20 years, said to have been taken suddenly ill. I found the patient in a state of profound repose, so to speak, with regular but rather labored breathing, bordering on stertor; a pulso full and pretty regular, thoingh not forcible; he was insensible; pinching or shouting was not appreciated; he was unable to swallow. In fact, on first examination, be appeared to be in just such a condition as one who had often seen the effects of opium in excess would have charged to that drug.; ; so I remarked, "This man seems to have poisoned hitnself with laudanum or morphia; wait, however, until I have examined his papils." The pupils were undoubtedly dilated, for I distinctly recollect having said, " It is not opium, but what it: is I cannot at present certaiply tell." Mry delay in reporting this case is due to not having made a memorandam at that time of tho precise condition of the pupils (great accuracy being, in my opinion, essential in all exhibits for the benefit of the profession); yet I was then plainly satisfied; be. ing familiar with opinm symptoms, that ino. such narcotic had been employed.

I concluded to act on geueral principles. Internal stimulants could not be giveh, as the patient could not swallow; so I detormined to keep up and increase respiration by the use of the electro-magnetic machine, uitil the unknown poisop had been eliminated by tho lungs; Just before leaving to obtain my machine, $I$, for the sake of his comfort, changed the position of the patient, who had been lying for several hours upon his back, to his side. In this movemont his pillow was displaced; when a bottle corked, containing a small quaritity of fluid with a few' shining crystals, rolled from beneath it. This fluid, on examination, appeared to be chloroform, yet thore was no odor of it in the room. The Marshal of Kentucky, who had charge of the man under a requisition from the Governor of Oliio, then recollected that towards morning his prisoner had risen, examined his valise, and quietly returned to bed, where he had remained just as quietly until the time when the marshal, failing to awaken him, became alarmed and sent for aid:

. On my way for the electro-magnetio ma: chine, I left the vial with Mr. E. S. Wayne; chemist, desiring an immediate analysis of its contents. Shortly afterwards be informed mo that the fluid submitted to him was 8 saturated solution of strychnia, with crystals in excess, in chloroform, and that if the bottle was originally full, it must hate contained an ounce of chloroform . with at least fifleen grains of stryohnia. On again reaching the patient, perhaps in an hour or less after leaving him, he was in the same quiet condition, withouta single strychnine symp. tom, though somewhat depressed and evidently anesthetized, which state the analysis of the fluid seemed to throw some light upon. I immediately commenced to pass regularly-successive electro-magnetic currents (by. Kidder's machine; with full pow's er) from the vape of the neck to the pitiof the stomach, in the ordinary: manner for: artificial respication, which wiere-continued more than an hour. During this time eensa'tion and cousciousness gradnally returned; thi patient then recogrized those abont him, and for some time slept, with brief intervals, tranquilly, . On awaking; and during Friday, he had nome general numbness: On Saturday, December '7th; 1867; very' trifling numbness ionly and some exhaustion remaining; his father determined on remov. ing him to his home in Kentucky: The trip is reported to have been attended by iusensibility, lasting thirty-six hours:- On February 11th, 1868, the father wrote me: "I do not know, but, judging from appearance, there is no trace of poison existing either in his mental or physical system?"

The chemical analysis of $\mathrm{Mr}$. Wayne and the observation of the marshal are fully. sustajned by the statement of the pationt;: whu had no knowledge of the examination, or observation, for he, in answer to my in. quiries, ssid that, supposing ohloroform and strychnine were the most certain poisons, he had abtaived from a druggist friend: the bottle of chloroform and fifteen cents' worth of stryclinine, to use in case of need. Being determined to destroy himself, he got out the preparation, and first inhaled all he could, but finding this did not prow duce the desired effect, swallowed all but: that which was found in the bottle under. the pillow.

It would thus appear that the patient had taken, before, I saw him, seren-eighths of an ounce of a saturated solution of 'strychnia, with crystals in excess, in chloroform, 
both by inhatation and ingestion, without any other result than complete and prolonged anæsthetization and some temporary subsequent numbeess; with no known injurious consequences after two months had elapsed:

The : case is reported as a contribution to toxicology, somewhat peculiar, as the strychnine effiets seem to have been destroyed from the beginning. It is therefore, perhaps, more marked, as far as the antidotal property of chloroform is concerned, than those quoted in the Uniled Slates Dispensalory, 12th edition, 1855, under "Stry chnia," p. 1357 , and in the footrnote to the same.*

In corroboration of the statement of Prof. Gobrecht, as to tho effects of chloroform as an antidota in the case of supposed poisoning from strychnia, Dr.. John L: Atlee; of Lencaster, related the following case :-

On Tuesday afternoon, about 2 o'clock; Allguat 218t, :1857, I was requested to see Mr. A. C.j aged about 60 years, a man of herculean frame and great musculan strength, who was faund in his chamber at tho, hotel, laboring under violent spasms. This man had at one time occupied a highly respectable position in the community in whioh he lived, and belonged to: one of the oldest and most: respecta. ble, families in the county. For several years he had been suspected of harboring horse-thieves and burglars at his tavern in the country, but by his consummate taot and cunning had eluded the vigilance of his neighbors who suffered from the depredations of the outlaws. In the beginning of the year 1857, however, he was accused of recoiving stolen property, and his trial was fxed for the April term of that year.; It did not, howeven, take place until the following tern; in August, when he was convicted of the offence. Heiwas dt dinner, at 1.o'clook, P.M., when he overheard the remark of a gentleman attending

- Ánd severál cases are on record in which the inhalation of chloroform' las not only atforded great relief, bus appeurs to have been the meutis of gaving lifo. Clitoriform lias becn used also with secming odvantage by the stomach. In a case recorded by Dr. Dresbach, of Tiffin, Ohlo, two drachms swallowed by a patient alarmingly ill from the effecte of three grains of strych. nia produced complete relief in less than fifteen minutes,"

And also in a foot-note :-

"In a letter to the nuthors from Dr. Wm. D. Barclay, dated Muscatine, Iowa, May 4, 1863, the case of a robust young mat is described; who, after taking four grains of stryclinia, was selzod with the most violent tetapic spasms, accompanied with intense suffering, and recovered inder the use of chloroform, given both in. ternally and by inhalation. It was necessary to keop him under the influence of the medicine for thirteen cousceutive hours, during which two pounds of chloroform were consumed hy inhalition. Two drops wero given every five minutes by the stomach; when the moputh could be openod." the court, that the jury had found him guilty. He immediately rose from the table, went to his chamber, $\because$ was seen to mix something in a tumbler with water, and drink it, and not long afterwards was found in the condition subsequently described: Dr. Charles L. Baker, a very intelligent young physician, now deceased, then boarding at the hotel, was called in to see him. Finding his symptoms peculiar, and the patient altogether unwilling to the medis cine, he sent for me.

Upon entering the room I found the patient in bed, lying npon his back, his countenance flushed, and with a stern and al: most demoniac expression; his pulse natiral, skin moist, and his intellectual fáculi ties perfect. Dr. Baker informed me that he suepected poison, and had endeavored to administer emetics ; but that the patient had obstinately refused all medical assistance. While recoiving this information a violent apasm seized the patient; which $\mathbf{I}$ observed was of a decidedly tetánic charaoter, similar to those previously observed; and which affected all the voluntary muscles. I told the doctor that I was sat: isfed the patient had taken strychnia. He had frequently declared; before his trial; that; if convicted, he would never suffer imprisonment.

Finding the patient obstinately bent on self-destruction, the use of the stomachpump was suggested, and Dr. B: went to proonro it." In bis absence I ifsed all my endeavors to induce the patient to take tho emetic, without avail ; and while pressing the cop :to his lipg I discovered that his jaw.s wore firmly olosed, that he had a full set of teeth, and that it would be iripossible; in a man of his great muscular strength and determination;" to" ase the stomachpump: It then ocourred to me that by means of chloroform a double object could be gained-a subjeotion of 'tho patient and a relief from the spasms. I went next door to the druggist; where I found Dr. B. preparing the stomaoh pump, procured two ounces of chloroform, and with him returned to the patient; whom I had left in the care of a student.

While's at the druggist's, I ascertained that at the April term of the court, when lue had expected the trial to come on, the patient had purchased there twenty graing of- stryolnia. This confirmed my stispicion ss to the cause of the symptoms, and showed the evident bent of his mind. On our return wo found the spasms increased in force and frequency.

By means of a fulded napkin tho chloro- 
form was applied to the mouth and nos a trils; but no sooner was it done than he grasped the napkin violently with his right hand, tore it away, and openly defied mo to administer remedies to bim. It then appealed to the gentlemen attending court, Who by this time nearly filled the room; to assist us in holding down the patient; and by this means-having two persons to each: arm and leg, and having the - head firmly held-I was enabled to use the anmsthetic. In a few moments it produced its effect; his whole muscular system became relaxed; and he remainod for ten or fifteen minutes perfectly quiescent. As soon as ho was restored to consciousness, we found that a total change, mental, moral and phyaical; had taken place. The spasms had left him, the expression of his countenanoe was calm and comparatively pleasant, and he was porfectly obedierit to every request made of him. He took the emetic without difficulty, and we soon had the satisfaction of sceing his stomach thoroughly evacuated. He had partaken of a portion, of his dinner. bofore swallowing the strychnia, which probably prevented a more rapid absorp. tiou of it. At this time, abaut: 3 o'clock, P.M., I had to leave him, for three hours, under the care of Dr. B., with the undere: standing that he would readminister the chloroform, should there be a recurrence of the spasms. At 6 o'olock, P.M.,.I found the patient apparently well ; there had been no spasms ; his mind was calm, his temper placid, and ho complained of nothing but weakness. He had a good uight, and the next morning, although suffering from mus, cular dobility, and some iunsteadiness in hig gait, he was brought bafore the court, and sentericed to confinement, in tho Hastern Penitentiary, where, a few weeks, afterwards, he committed suicide, by hanging, in his coll.-Trans. Penn... State Med. Soo.

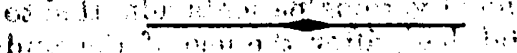

$$
\begin{aligned}
& \text { EXPERIMENTAL RESEAROHES ON THE }
\end{aligned}
$$

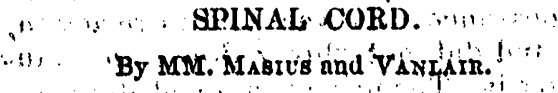

Tif apthors commence thair memoir with a histalogical examination of the filum termi-: natg of the spipal cord of the frog. At its posterior extremity this filum is exclusively formed of layers of epithelial cells, sur-" rounded on the outside by the pia mater, and enclosing a canal which ends in a culdersac. More in front they find, beyond the epittielial mass, some large multipolar. cello, with nuclous and nucleolus (nerve cells lying between the pia mater and tho opithelium; still more anteriorly; they ob serve pale, varicose, and longitudinal hervefibres, the existencee of which Kolliker had already pointed out. At the point of emergence from the coccygeal canal, the stratum of radiating cells and fibres gradially becomes thicker as far as the brigin' of the tenth spinal nerve. The prolong'ations of the nerve cells are continuous "with tliose of the epitbelial cells: Upon the lateral and anterior ifaces of the filum terminale at this: point, the multipolar cells approach each other, and admit in the narrow intervals between them longituditial fibres, to which they at length give place. The authors compare the results of their labors with former works on the same subject with reference to man and the frog; and conclude: that the filum terminale of the adult frog: resembles the buman spinal cord checked in its development, so that each segment of the filum represents ione of the successive phases through which the humen cord passes in its primary formation. ' 7 . is:?

Whe second part of the memoir has refer: encerto the experiments which the suthors made to delermine the: corresponding ovita: neaus: and medullary, regiane" (territotreg)" of the spinal nerves of : the frog ; "al "subject. already : handled by Peyer, Türk, Krausej" Eckhardt, aud Koschennikoff!".'The results" agree more or less with thoso of the lastnamed author. They prove : further'that there is no root presiding exclusively over: the perceptive (consoiente) senslbility, and that the cutaneous region, the irritation of: which provukes a perceptive sensibillty, is for eagh nerve the same:as that: which can produco (a! reflex uction; : an' observation whiah is opposed to Marshall Flall's hypo-: thesis regarding the excito-motory: fibres:

Passitig to the medultary region of the posterioriroots of the frog, the authors ad-i. mitrthatiall thei fibres for percoptiver sensa's! tions ought to end, directly or indirectly; in the bruin ; but there are centres, espocially at oach root, which regulate the ruflex movements. 'Their results, as regards the position of the centres of reflex action,! agree on the. whole with those of M. Ko schepnikoff; but in detail they present niaiked diflerences, which the authors ex: plain by the inconstancy both of the cutaneous, regions and of the points of emem genoe of the roots. To aroid as far ds pos. sible the diminution of irritability consequent on 80 serious an operation as openiiig the vertiobral oanal, they made each experiment, uponi an uninjured frog, by a sin-1 gle cut, and then tested the persistence of thio ręlex oxcitability. An autopsy was 